\title{
NON-LINEAR ANALYSIS OF FRAME REINFORCED CONCRETE BRIDGE- SHALLOW VS. PILE FOUNDATION
}

\author{
NELINEARNA ANALIZA OKVIRNOG AB MOSTA FUNDIRANOG NA PLITKIM \\ TEMELJIMA I NA ŠIPOVIMA
}

\author{
Alexander ILIEV \\ Dimitar DIMITROV \\ Dimitar STEFANOV
}

\author{
ORIGINALNI NAUČNI RAD \\ ORIGINAL SCIENTIFIC PAPER \\ UDK:624.21.012.45 \\ doi:10.5937/GRMK1904003!
}

\section{INTRODUCTION}

The bridge design includes the choice of the bridge structural system, materials, section dimensions, aesthetics and economic considerations. In EN 1998-2 [1] the main principle is that bridges behave in case of seismic action in a ductile or limited ductile/essentially elastic manner. In regions of moderate to high seismicity is preferable to design a bridge for ductile behaviour. The bridge deck shall remain within elastic range. The formation of the plastic hinges is allowed in the piers which are the energy dissipating bridge components.

The theoretical investigations and the experience from the past earthquakes show that the continuous bridge structures behave better than bridges with many expansion joints and bearings.

The frame bridges have advantageous "ductile behaviour of the structure" during the seismic event. In this case the seismic action is considerably reduced in comparison with the other bridges, for instance bridges with elastomeric bearings. According to EN 1998-2 [1], the structural behaviour of the last ones is ductile limited. This leads to significant difficulties in the satisfaction of the bearing checks, increased dimensions of the substructure elements and the reinforcement. Anchorage of the bearings is a common design solution for the bridges

Alexander lliev, National Institute of Geophysics, Geodesy and Geography- Bulgarian Academy of Sciences. Sofia, Bulgaria

Dimitar Dimitrov, National Institute of Geophysics, Geodesy and Geography- Bulgarian Academy of Sciences. Sofia, Bulgaria

Dimitar Stefanov, National Institute of Geophysics, Geodesy and Geography- Bulgarian Academy of Sciences. Sofia, Bulgaria in high risk seismic areas. The author's opinion is that the frame bridges application will be extended due to these reasons. Of course, the detailing rules for the ductile behaviour should be strictly followed.

The design of flexible piers reduces the seismic action but the displacements are increased. The second order effects might be significant.

According to EN 1998-2 [1] the maximum allowable seismic action reduction coefficients (behaviour factors q) are:

- $\mathrm{q} \leq 3.5$ for vertical piers with ductile behaviour;

- $\mathrm{q} \leq 2.1$ for inclined ones.

The coefficients $q$ depend on the ratio $\alpha_{s}=L / h$, where $L$ is the distance between the plastic hinge and the section with zero bending moment and $h$ is the cross section dimension in the direction of the bending.

The influence of the normal force at the section with plastic hinge should be taken into account. The normalized force is $\eta_{k}=N_{E d} /\left(A_{c} f_{c d}\right)$. Piers with $L / h<1$ and/or $\eta_{k}>0.60$ should be avoided. In these cases the ductile behaviour is not ensured. The vertical seismic action increases the normal force $N_{E d}$ at the plastic hinge section, i.e. the $q$-coefficient is reduced. This influence is analyzed in the paper.

These values are used only for "linear analysis" and only in horizontal direction. It is allowed, based on the designer's and/or client's evaluation, to apply smaller $q$ values.

The best way for the determination of the ductility is the static non-linear (push-over) analysis. According to EN 1998-2 [1] this analysis could be applied for the whole bridge structure or for a single pier. At the paper a model of the whole structure is done and the ductility is determined from the results for a single pier. Using this 
approach, a comparison between the design ductility and the nominal ductility based on [1] could be done.

The vertical seismic action application is different for the buildings [2] and for the bridges [1]. If a push-over analysis is performed for a building, then the vertical seismic component could be neglected. This component should be applied for bridges with pre-stressed reinforced concrete superstructure. The recommended basic period $T_{1}$ of the bridge structure is between 1 and $2 \mathrm{sec}$ for balance between the internal forces and the displacements. The calculated periods in the analysis are within these limits - see below.

The aims of the presented analysis in the paper are:

- Determination of the "real" ductility in the case of seismic action separately in longitudinal and transversal bridge direction using non-linear analysis;

- Comparison between the structural ductility between a bridge with flat footing and one with piles;

- Comparison between the "real" ductility and the "nominal" one based on EN 1998-2 [1];

- Evaluation of the influence of the vertical seismic action component to the bridge structural ductility.

\section{BRIDGE STRUCTURE MODEL}

The static non-linear analysis is reliable and applicable for bridge structures, which behaviour is similar to ones that could be approximated with a "single degree of freedom" model. Such bridges are approximately straight bridges and ones with negligible pier height change. The selected case study bridge meets these requirements.

The bridge is a three span frame one and it is situated on a motorway. The spans are $33+41+33 \mathrm{~m}$ and the total bridge length is $107 \mathrm{~m}$. The length is less than $L_{\text {lim }}$ according to [1] and the spatial variability of the seismic action shall not be considered.

The superstructure is a cast-in-place pre-stressed post-tensioned reinforced concrete one. The cross section is a hollow one with three cells- see Fig.1. The constant height of the section is $2 \mathrm{~m}$. The concrete class is $\mathrm{C} 45 / 55$.

The piers are reinforced concrete solid "wall" type ones with $14 \mathrm{~m}$ height. At the top of the pier the solid cross section is separated into 2 parts for better connection with the superstructure - see Fig.2. The pier concrete class is $\mathrm{C} 35 / 45$. The reinforcement class is B500C $\left(f_{y k}=500 \mathrm{MPa}\right)$.

The bearings at the abutments are movable in both directions.
Two options for the foundations are selected:

- flat single footing

- drilled shaft piles with pile cap - 2 piles with $1.8 \mathrm{~m}$ diameter and $20 \mathrm{~m}$ length.

The longitudinal bars are $36 Ф 25 \mathrm{~mm}+10 \Phi 22 \mathrm{~mm}$. The stirrups are with $14 \mathrm{~mm}$ diameter.

The bridge is situated at a site with reference maximum soil acceleration $a_{g R}=0.32 g=3.14 \mathrm{~m} / \mathrm{sec}^{2}$. The importance coefficient is $\gamma_{I}=1.4$. Then the design soil acceleration is $a_{g}=1.4^{\star} 0.32 g=0.448 g=4.40 \mathrm{~m} / \mathrm{sec}^{2}$.

According to [2] the push-over analysis is carried out:

- applying constant vertical actions. The traffic action is a load model LM1. According to the Bulgarian NA (National Annex) for road bridges with reinforced concrete superstructure quasi-permanent value of the action is assumed, i.e. $\psi_{2}=0.20$ for bridges on the highway;

- applying permanently increasing horizontal seismic actions.

The bridge model consists of 52446 finite elements: 21292 solid elements (8 nodes) for the concrete structure, 30978 shell elements for the reinforcement (smeared approach) and 176 truss elements representing the pre-stressing system (Fig.3). Average size of the solid element of the bridge structure is around $0,5 \mathrm{~m}$. The connection between the columns and the top structure is considered rigid (united nodes). The soilstructure interaction is represented with two concrete piles for each column with elastic springs in both horizontal directions. The two ends of the bridge are also supported with vertical elastic springs representing the polymer joint connecting the top-structure to the columns (pinned connection). The full model of the bridge is presented in Fig.2.

For the numerical analyses standard implicit HilberHughes method was used. Nonlinear behaviour of concrete is modelled with Ottosen constitutive model [3][7]. Crack formation and propagation is based on the smeared crack approach. The iteration method is BFGS combined with energy convergence criteria [6]. Two nonlinear static (pushover) analyses are performed for the bridge, one in each horizontal direction. The analyses use monotonic mass proportional load vector in both directions.

The stiffness of the elements is updated with every step of the calculation based on the accumulated deformations and the work diagram (stressdeformations) of concrete constitutive material model. Fig. 4 shows the working diagram of concrete for one dimensional stress state.

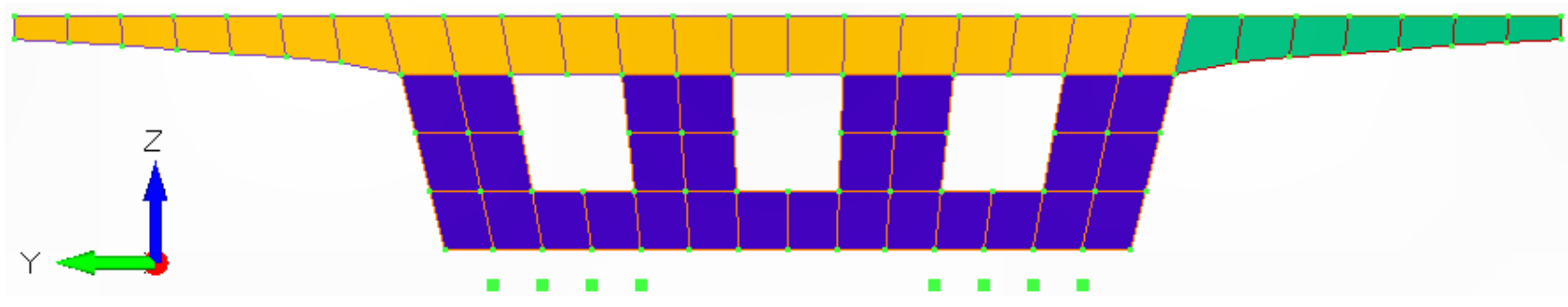

Fig. 1. Section cut of the top system 


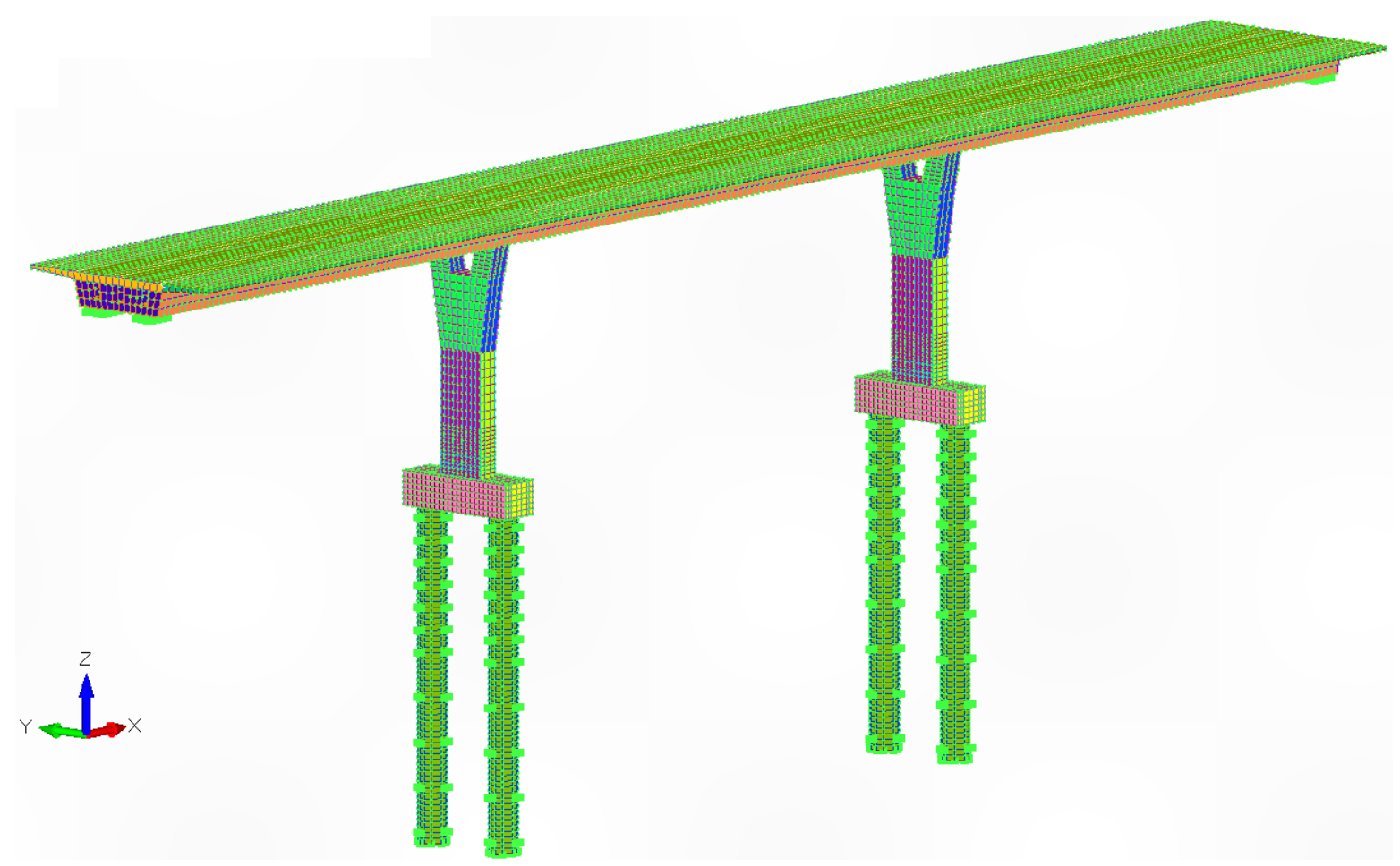

Fig. 2. Tree-dimensional view of the finite element model. Pile foundation case study

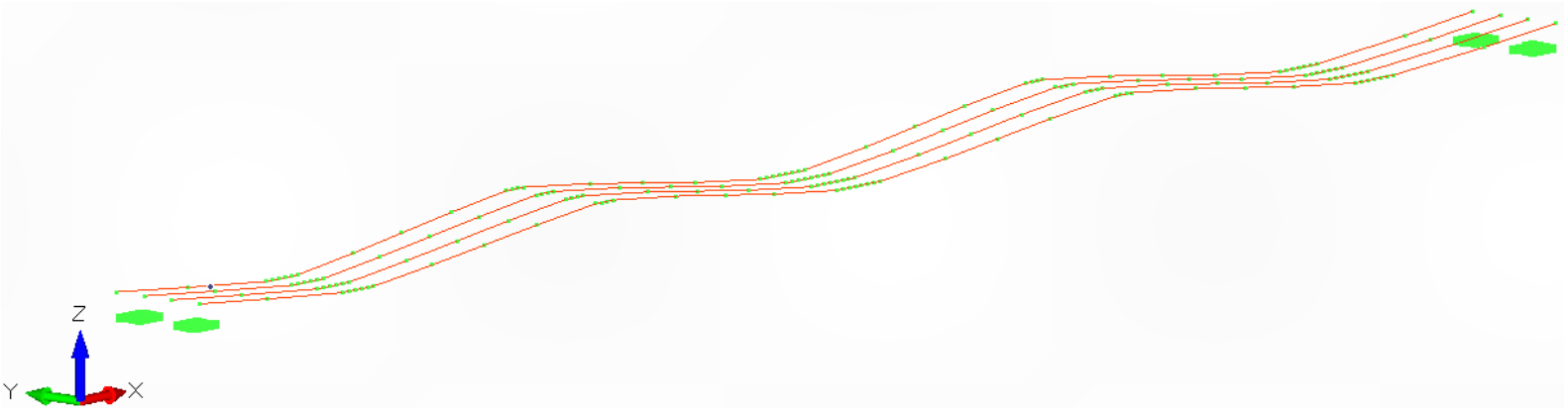

Fig. 3. Spatial geometry of the pre-stressing system

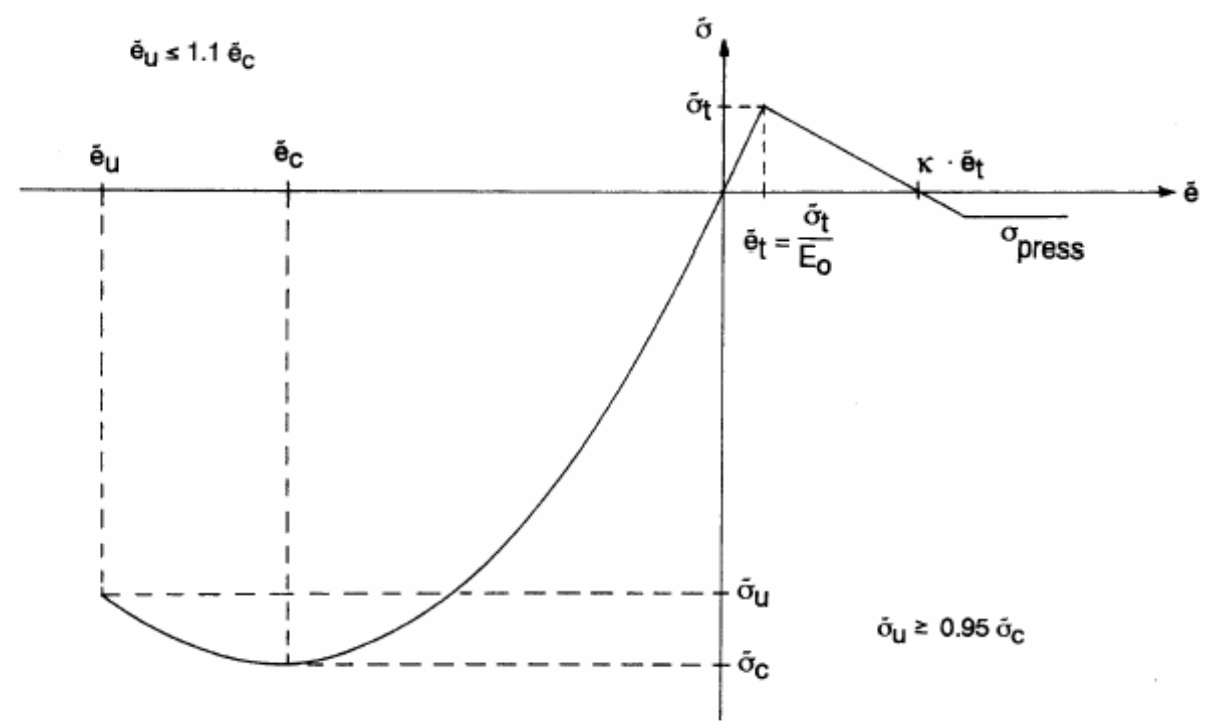

Fig. 4. One dimensional stress state of concrete material model 
The type of the stress condition of the element influences significantly to the strength-deformation concrete characteristics. The damage criterions are based on comparison between the current stress condition and the limit (allowable) concrete stresses see the envelope curve at Fig.5.

\section{RESULTS}

\section{Behaviour coefficients according to EN 1998-2 [1]}

The preliminary determination of the behaviour coefficients is based on the following assumptions:

- in longitudinal direction the length $L$ is a half pier clear length;

- in transversal direction the length $L$ is a full pier clear length plus the distance to the centre of the gravity of the superstructure, i.e. the plastic hinge is at the bottom of the pier and the behaviour is similar to cantilever.

The results are presented in the Table 1.

The distance from the top pier section to the centre of the gravity of the superstructure is $z_{c}=1130 \mathrm{~mm}$. Then in the transversal direction $L=14+1.13=15.13 \mathrm{~m}$.

\section{Plastic hinge length}

The plastic hinge length is according to Annex $E$ from [1] using the formula (1).

$$
L_{P}=0.10 L+0.015 f_{y k} d_{b L}
$$

where:

$d_{b L}=25 \mathrm{~mm}$ is the maximum diameter of the pier longitudinal reinforcement

$L_{P}=0.10 L+0.015 * 500 * 25=0.10 L+188$

The relevant lengths are:

- in longitudinal direction the length

$L_{P}=0.10 * 7000+188=888 \mathrm{~mm}$;

- in transversal direction the length $L_{p}=0.1 * 15130+188=1701 \mathrm{~mm}$.

\section{Procedure for the determination of the member displacement ductility factor $\mu_{\Delta}$ and curvature ductility factor $\mu_{\Phi}$}

The displacement ductility factor $\mu_{\Delta}$ could be determined using two possibilities:

A. Determination from the model and the push-over analysis of the displacement at yielding $\Delta_{y}$ and ultimate displacement $\Delta_{u}$ - see Fig.6. The displacement $\Delta_{u}$ is obtained when the strain at the concrete and/or steel reaches the maximum values - see below.

$$
\mu_{\Delta}=\Delta u / \Delta y
$$

B. Analytical calculation according to Annex B from EN 1998-2 [1] :

$$
\begin{gathered}
\mu_{\Phi}=1+\left[\mu_{d}-1\right] /[3 \lambda(1-0.5 \lambda)] \\
\mu_{d}=1+\left(\mu_{\Phi}-1\right) 3 \lambda(1-0.5 \lambda)
\end{gathered}
$$

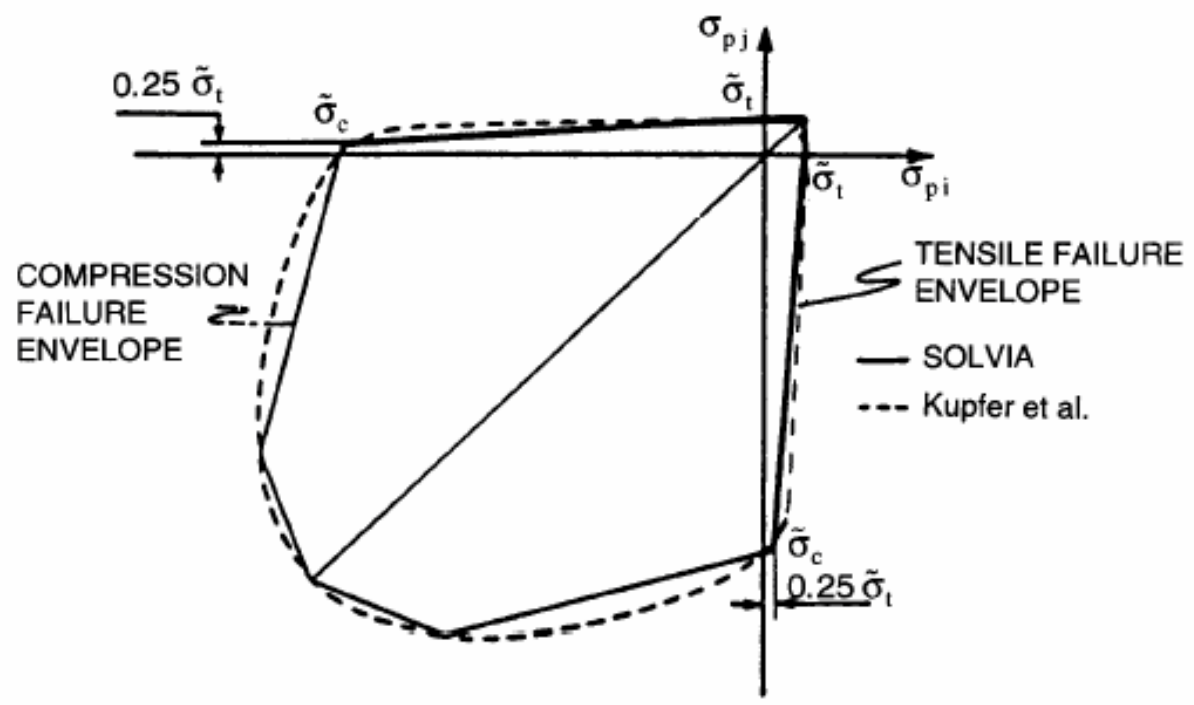

Fig. 5. Capacity (limit) envelope of concrete. Plane model

Table 1.

\begin{tabular}{|c|c|c|c|c|c|}
\hline Direction & $L[m]$ & $h[m]$ & $\alpha_{s}=L / h$ & $\lambda_{s}=\left(\mathrm{\alpha}_{\mathrm{s}} / 3\right)^{1 / 2}$ or 1 if $\lambda_{s}>3$ & $q=3.5 \lambda s$ \\
\hline Longitudinal $-x$ & $14 / 2=7$ & 1.35 & 5.18 & 1 & 3.5 \\
\hline Transversal $-y$ & 15.13 & 3 & 5.04 & 1 & 3.5 \\
\hline
\end{tabular}


where: $\lambda=L p / L$

This formula is used for elements which behaviour is similar to the cantilever, i.e. for the piers in the transversal direction.

$$
\mu_{\Phi}=\Phi_{u} / \Phi_{y}
$$

The ultimate curvature $\boldsymbol{\Phi}_{u}$ is determined according to Annex E from [1]:

$$
\Phi_{u}=\left(\varepsilon_{s}-\varepsilon_{c}\right) / d
$$

where:

- $\mathrm{d}$ is the effective depth;

- $\varepsilon_{\mathrm{s}}$ and $\varepsilon_{\mathrm{c}}$ are the steel and concrete strains respectively (concrete strain with sign "-").

They separately or both reach the following maximum strains:

a. maximum strain of the unconfined concrete $\varepsilon_{c u 1}$ according to EN 1992-1-1 [2]. For concrete class C35/45 $\varepsilon_{\text {cu } 1}=3.5 \%$

b. maximum strain of the confined concrete $\varepsilon_{c u, c}$ according to Annex $E$ from [1] - see below.

c. maximum steel strain $\varepsilon_{s u}$ at maximum force. For steel B500C (ductility class $\mathrm{C}$ is required for structures at high seismic areas) $\varepsilon_{s u}=75 \%$.

In the paper the following maximum strains are assumed:

- for the confined concrete $\varepsilon_{\mathrm{cu}, \mathrm{c}}=14.36 \%$ - see below

- for the steel $\varepsilon_{\mathrm{su}}=75 \%$

The calculation of the maximum strain of the confined concrete $\varepsilon_{c u, c}$ is according to:

- the transversal reinforcement ratio $\rho_{w}$ in the two transverse directions 2 and 3 (direction 1 is along the pier axis)

- the coefficient of the effectiveness of the confinement $\alpha=\alpha_{n} \alpha_{s}$

- for the piers with minimum cross section dimension $b=1 \mathrm{~m}$ could be assumed $\alpha=1$. In the presented paper $b>1 m$ and then $\alpha<1-$ see below

- the effective confined stress $\sigma_{e}$ at the concrete

- the ultimate strength of the confined concrete $f_{\mathrm{cm}, \mathrm{c}}$

The average concrete strength of the unconfined concrete $f_{c m}$ according to [2] is:

\section{$f_{c m}=f_{c k}+8=35+8=43 \mathrm{MPa}$.}

The calculation for the effective confined stress $\sigma_{e}$ is presented in the following Table 2.

$$
\varepsilon_{c 1, c}=0.002[1+5(1.3535-1)]=0.005535(5.53 \% \text { ) }
$$

The maximum strain of the confined concrete $\varepsilon_{c u, c}$ is:

$\varepsilon_{c u 1, c}=0.004+\left(1.4^{*} \rho_{s}{ }^{*} f_{y m}{ }^{*} \varepsilon_{s u}\right) / f_{c m, c}$, where:

$\rho_{s}=2 \rho_{w}$ in case of rectangular stirrups.

It is ambiguously defined in [1] the determination of the ratio $\rho_{w}$ in the case of different ratios in two directions - $\rho_{w 2} \neq \rho_{w 3}$. In the paper it is assumed $\rho_{w}=\left(\rho_{w 2} \rho_{w 3}\right)^{1 / 2}$.

$$
\begin{aligned}
& \rho_{w}=\left(0.00567^{*} 0.00582\right)^{1 / 2}=0.00574 \\
& \rho_{s}=2 \rho_{w}=2^{*} 0.00574=0.01148 \\
& \begin{aligned}
\varepsilon_{c u 1, c} & =0.004+\left(1.4^{*} 0.01148^{*} 500^{*} 75^{*} 10^{-3}\right) / 58.2= \\
& =0.01436(14.36 \% \text { o })
\end{aligned}
\end{aligned}
$$

The calculated values for $f_{c m, c,} \varepsilon_{c 1, c}$ and $\varepsilon_{c u 1, c}$ correspond well with the experimental results [4].

The following requirements according to [1] are checked and controlled:

- The analysis is based on Annex $\mathrm{H}$. The "target displacement" of the "reference point" is controlled. The "reference point" is the centre of masses of the superstructure.

- The rotations $\theta_{\mathrm{p}, \mathrm{E}}$ at the plastic hinges are checked according to 4.2.4.4 of [1].

$\theta_{p, E}<\theta_{p, d}$, where $\theta_{p, d}$ is the design value of the plastic rotation capacity and it is calculated from the formula

where:

$$
\theta_{p, d}=\theta_{p, u} / Y_{R, p}
$$

- $\theta_{p, u}$ is determined according to Annex $E$ from [1] see formula (8)

- $Y_{R, p}=1.40$ in the case of missing data from experiments.

$$
\theta_{p, u}=\left(\Phi_{u}-\Phi_{y}\right) L_{p}\left(1-L_{p} / 2 L\right)
$$

Determination of the member displacement ductility factor $\mu_{\Delta}$ and curvature ductility factor $\mu_{\Phi}$ at longitudinal direction and in the case of flat foundation

The distribution of deformations is presented at Fig.6. The compressive failure of concrete is labelled as "CRUSHED" and coloured in red. The tensile failure is coloured in different parts of green depending on the number of cracks in the cross section. The following results can be observed:

Table 2.

\begin{tabular}{|c|c|c|c|c|c|c|c|}
\hline$\rho_{w 2}$ & $\rho_{w 3}$ & $\alpha_{n}$ & $\alpha_{s}$ & $\alpha=\alpha_{n} \alpha_{s}$ & $\sigma_{e 2}[\mathrm{MPa}]$ & $\sigma_{e 3}[\mathrm{MPa}]$ & $\sigma_{e}=\left(\sigma_{e 2} \sigma_{e 3}\right)^{1 / 2}$ \\
\hline 0.00567 & 0.00582 & 0.9327 & 0.9317 & 0.869 & 2.46 & 2.53 & 2.49 \\
\hline
\end{tabular}

$$
\begin{aligned}
& f_{c m, c}=f_{c m}{ }^{*} \lambda_{c} \\
& \sigma_{e} / f_{c m}=2.49 / 43=0.0579 \\
& \lambda_{c}=2.254^{*}\left(1+7.94^{*} \sigma_{e} / f_{c m}\right)^{1 / 2}-2^{*} \sigma_{e} / f_{c m}-1.254= \\
& \quad=2.254^{*}\left(1+7.94^{*} 0.0579\right)^{1 / 2}-2^{*} 0.0579- \\
& -1.254=1.3535 \\
& f_{c m, c}=43^{*} 1.3535=58.2 \mathrm{MPa}
\end{aligned}
$$

The confined concrete strain $\varepsilon_{c 1, c}$ at $\sigma_{c}=f_{c m, c}$ is:

$$
\varepsilon_{c 1, c}=0.002\left[1+5\left(\lambda_{c}-1\right)\right]
$$

- maximum displacement of the reference point $\Delta_{\mathrm{u}}$ $=59.5 \mathrm{~cm}$ - see Fig.7;

- displacement of the reference point at yielding $\Delta_{y}$ $=6.5 \mathrm{~cm}$ - see Fig.7;

- maximum strain at the tensile reinforcement $\varepsilon_{\text {su }}=75 \%$ - see Fig.8;

- maximum stress at the tensile reinforcement $\sigma_{\mathrm{s}}=675 \mathrm{MPa}$ - see Fig.9; 
- maximum strain at the concrete $-\varepsilon_{\mathrm{c}}=-9.3 \%$. The strain is less than $\varepsilon_{c u 1, c}=14.36 \%$;

- the fundamental response period $-1 \mathrm{sec}<\mathrm{T}_{1}=1.21$ $\sec <2$ sec.

The recommended value [5] for $\Delta_{y}$ is $\Delta_{y}=0.005 \mathrm{H}$, where $\mathrm{H}=15.13 \mathrm{~m}$ is the distance between the centre of gravity of the superstructure and the base of the pier.

$\Delta y=0.005 H=0.005^{*} 15.13=0.076 \mathrm{~m}$
The effective depth of the cross section is $\mathrm{d}=1273=1.273 \mathrm{~m}$

The displacement ductility factor is:

$\mu_{\mathrm{d}}=\Delta u / \Delta_{y}=59.5 / 6.5=9.15$

The ultimate curvature is:

$\Phi_{u}=\left(\varepsilon_{s}-\varepsilon_{c}\right) / d=\left[75-(-9.36) * 10^{-3}\right] / 1.273=0.0663[1 / \mathrm{m}]$

The curvature at yielding is $\Phi_{y}=0.0045[1 / \mathrm{m}]$ - see Fig. 10 .

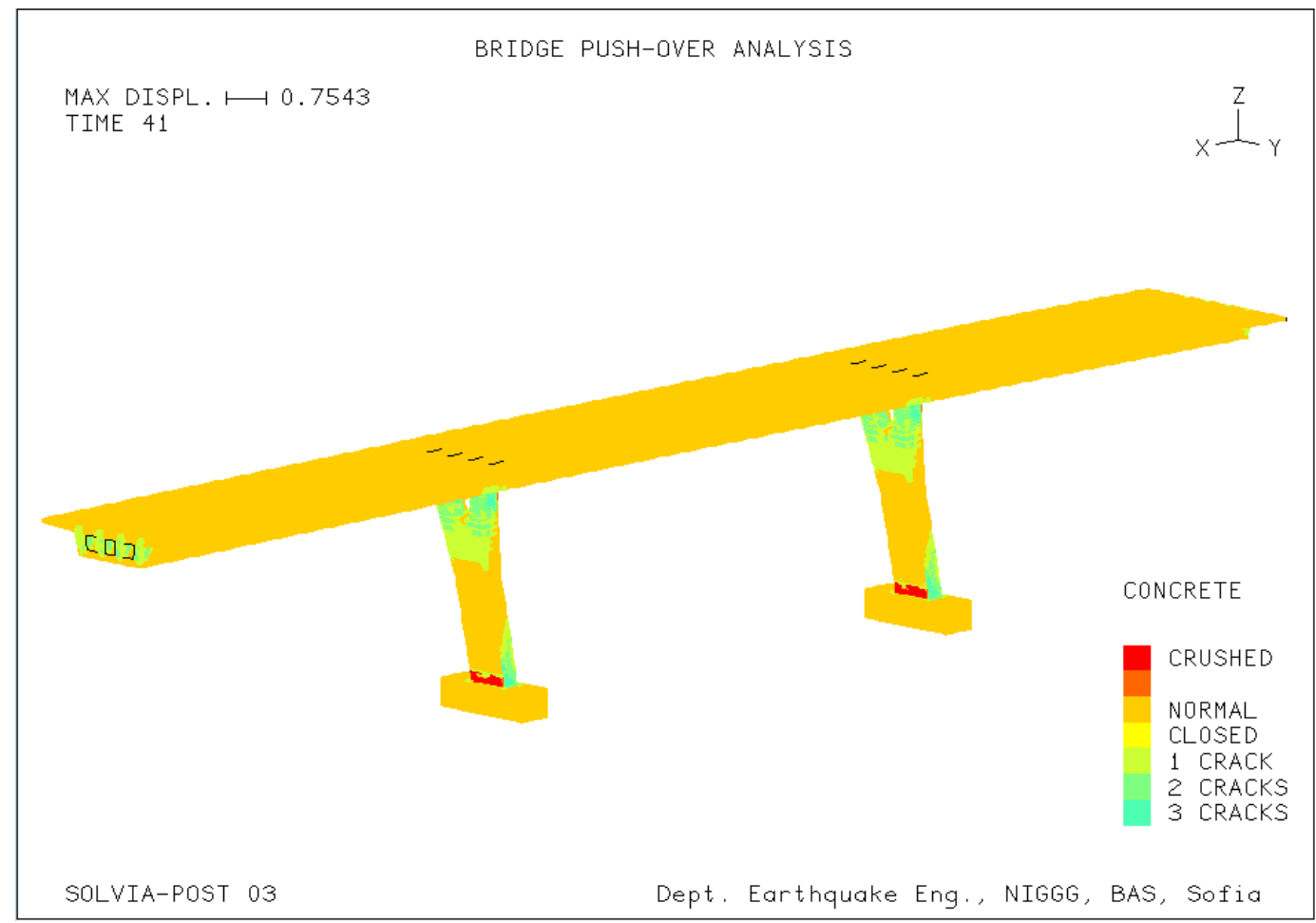

Fig. 6. Damage distribution in the bridge in longitudinal direction. Flat foundation case study.

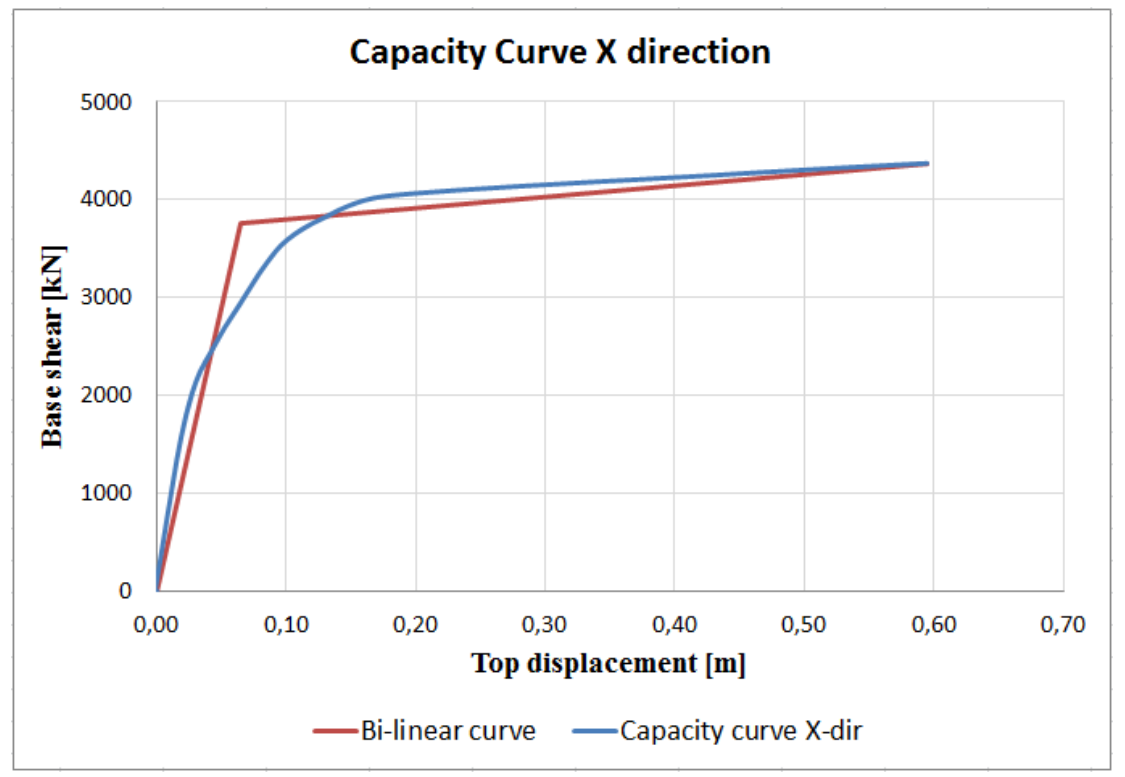

Fig. 7. Push-over (capacity) curve for the flat foundation case study 


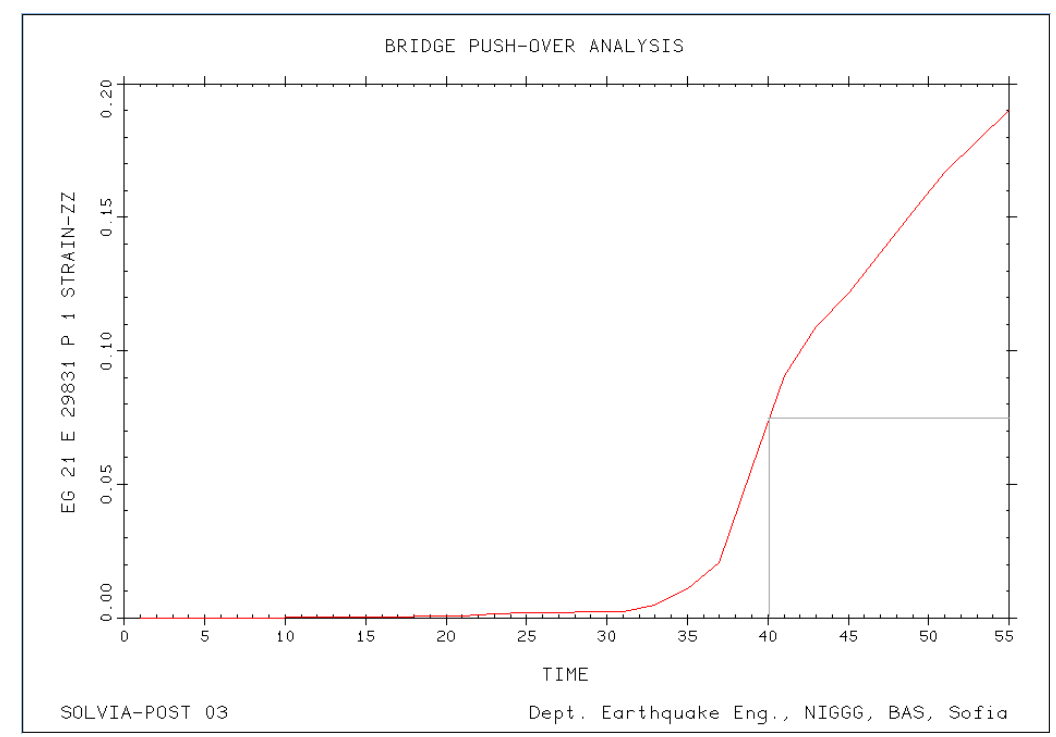

Fig. 8. Strain distribution in the tensile reinforcement at the base of the pier. Flat foundation.

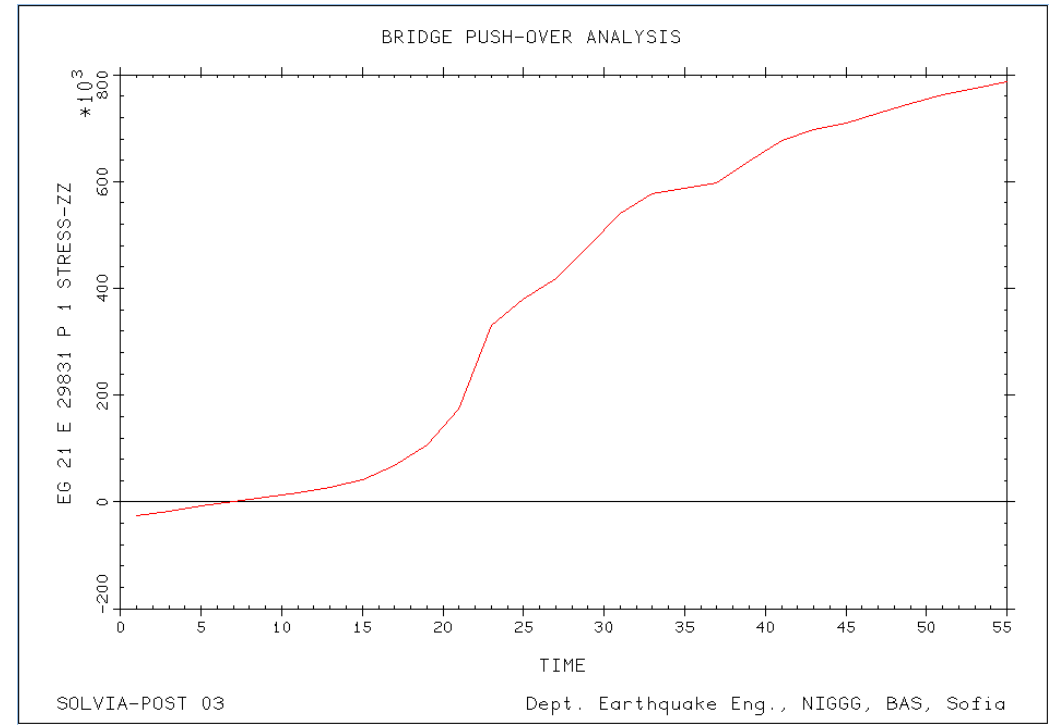

Fig. 9. Stress distribution in the tensile reinforcement at the base of the pier. Flat foundation,

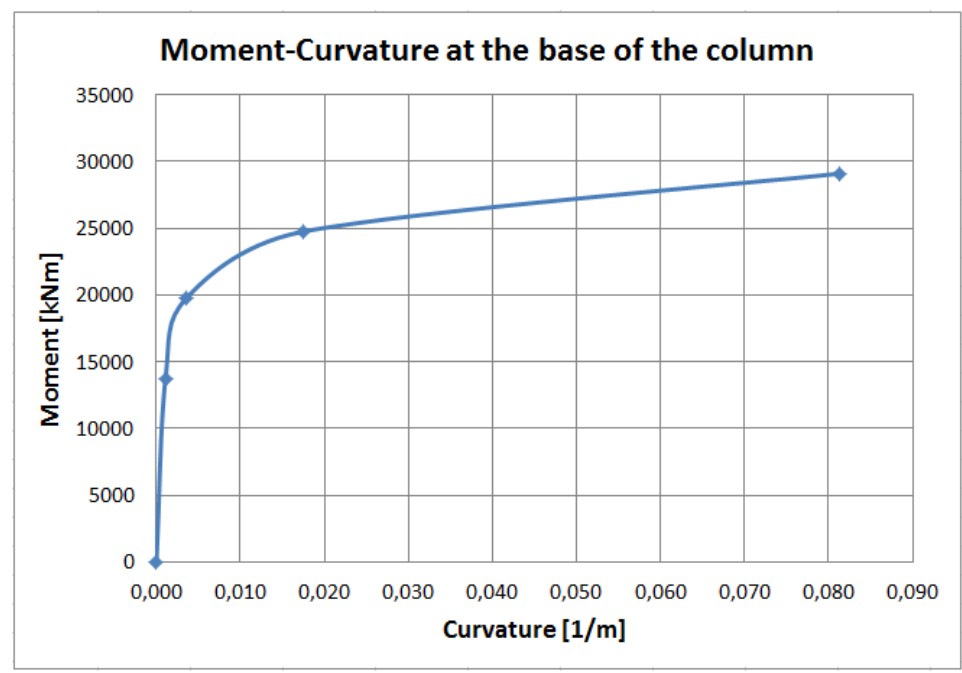

Fig. 10. Moment-curvature relationship at the base of the pier. Case study-flat foundation. 
The curvature ductility factor $\mu_{\Phi}$ is:

$\mu_{\Phi}=\Phi_{u} / \Phi_{y}=0.0663 / 0.0045=14.73$

The length of the plastic hinge is $L_{p}=0.888 \mathrm{~m}$ and the distance to the zero moment is $L=7 \mathrm{~m}$.

The plastic rotation capacity is:

$$
\begin{aligned}
\theta_{p, d} & =\theta_{p, u} / Y_{R, p} \\
\theta_{p, u} & =\left(\Phi_{u}-\Phi_{y}\right) L_{p}\left(1-L_{p} / 2 L\right)= \\
& =(0.0663-0.0045)^{*} 0.888^{*}\left(1-0.888 / 2^{*} 7\right)= \\
& =0.0514[\mathrm{rad}] \\
\theta_{p, d} & =\theta_{p, u} / \gamma_{R, p}=0.0514 / 1.4=0.0367[\mathrm{rad}]
\end{aligned}
$$

The rotations $\theta_{p, E}$ at the plastic hinge is:

$$
\begin{aligned}
\theta_{p, E} & =\Delta p /(H-L p)=(0.595-0.065) /(15.13-0.888)= \\
& =0.0372[\mathrm{rad}]
\end{aligned}
$$

Determination of the member displacement ductility factor $\mu_{\Delta}$ and curvature ductility factor $\mu_{\Phi}$ in TRANSVERSAL direction and in the case of flat foundation

The presented approach is applied in the transversal bridge direction. Due to the higher stiffness the ultimate curvature is at maximum concrete strain $\varepsilon_{c u 1}=3.5 \%$. The steel strain $\varepsilon_{s u}=46 \%$ o $75 \%$ o. The results are presented in the Table 3.

The length of the plastic hinge is $L_{p}=1.701 \mathrm{~m}$ and the distance to the zero moment is $L=15.13 \mathrm{~m}$.

$$
\lambda=L p / L=1.701 / 15.13=0.1124 \text {. }
$$

The displacement ductility could be calculated using formula (4), because in the transversal direction the behaviour is similar as a cantilever - Fig. 11 .

$$
\begin{aligned}
& \mu_{d}=1+\left(\mu_{\Phi}-1\right) 3 \lambda(1-0.5 \lambda)=1+(13-1) 3^{*} 0.1124\left(1-0 .{ }^{*} 0.1124\right)= \\
& =4.82 \\
& \left(\mu_{d}=4.29 \text { from the push-over analysis }-\right. \text { see Table 3) } \\
& \text { The plastic rotation capacity is: } \\
& \theta_{p, u}=\left(\Phi_{u}-\Phi_{y}\right) L_{p}\left(1-L_{p} / 2 L\right)=(0.0169-0.0013){ }^{*} 1.701^{*} \\
& *(1-1.701 / 2 * 15.13)=0.025[\mathrm{rad}] \\
& \theta_{p, d}=\theta_{p, u} / Y_{R, p}=0.025 / 1.4=0.0179[\mathrm{rad}]>\theta_{p, E}= \\
& =(0.193-0.045) /(15.13-1,701)=0.011[\mathrm{rad}]
\end{aligned}
$$

The distribution of deformations in transverse direction is presented in Fig.11.

Determination of the member displacement ductility factor $\mu_{\Delta}$ and curvature ductility factor $\mu_{\Phi}$ in LONGITUDINAL direction and in the case of PILE foundation.

The results of the case study with pile foundation are as following:

- maximum displacement of the reference point $\Delta_{u}$ $=100 \mathrm{~cm}-$ see Fig. 13 ;

- displacement of the reference point at yielding $\Delta_{y}$ $=13.5 \mathrm{~cm}-$ see Fig. 13 ;

- maximum strain at the tensile reinforcement $\varepsilon_{s u}=75 \%$ - see Fig. 14 ;

- maximum stress at the tensile reinforcement $\sigma_{\mathrm{s}}=630 \mathrm{MPa}-$ see Fig. 15

The displacement ductility factor is:

$\mu_{d}=\Delta_{u} / \Delta_{y}=100 / 13.5=7.41$

This value is less than the one determined for the case with flat foundation.

Table 3.

\begin{tabular}{|c|c|c|c|c|c|c|}
\hline$\Delta_{u}[\mathrm{~cm}]$ & $\Delta_{y}[\mathrm{~cm}]$ & $\mu_{d}=\Delta_{u} / \Delta_{y}$ & $\Phi_{u}=\left(\varepsilon_{s}-\varepsilon_{c}\right) / d[1 / \mathrm{m}]$ & $\Phi_{y}[1 / \mathrm{m}]$ & $\mu_{\Phi}=\Phi_{u} / \Phi_{y}$ & $\mathrm{~T}_{1}[\mathrm{sec}]$ \\
\hline 19.3 & 4.5 & 4.29 & {$\left[46-(-3.5)^{*} 10^{-3}\right] / 2.923=0.0169$} & 0.0013 & 13 & $1<1.19<2$ \\
\hline
\end{tabular}

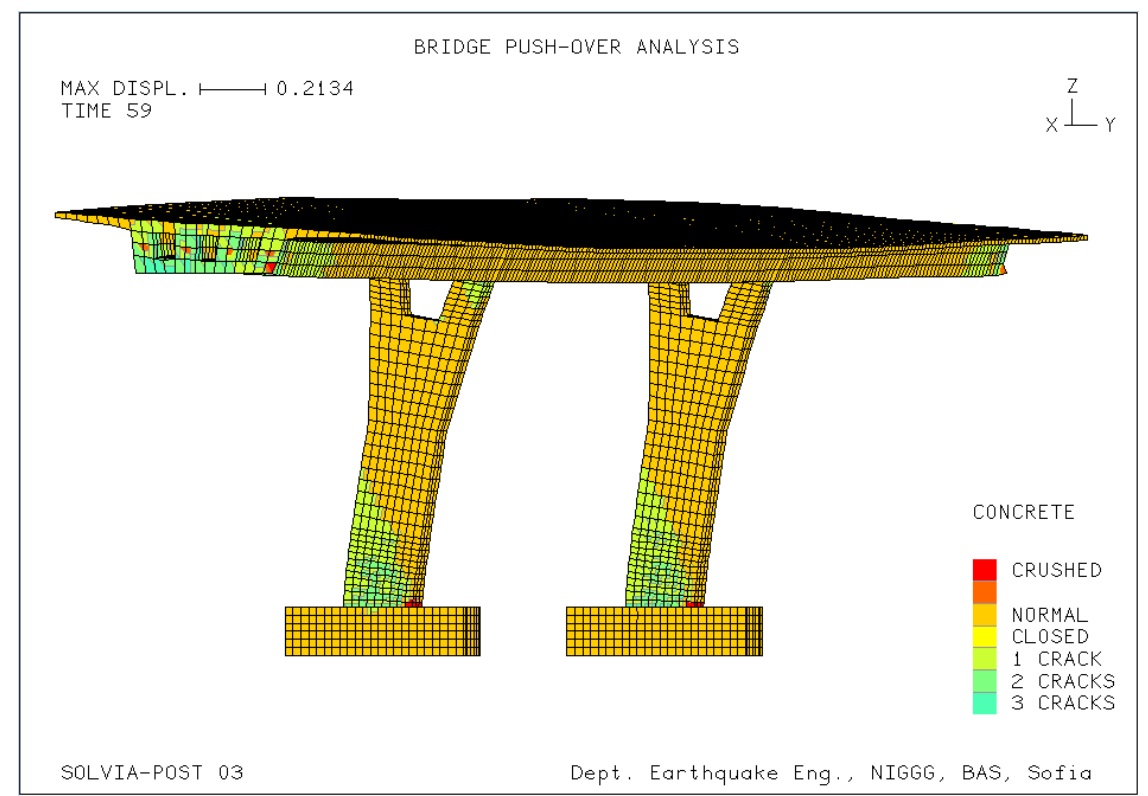

Fig. 11. Damage distribution in the bridge in transverse direction. Flat foundation case study. 
MAX DISPL. $\longmapsto 0.82541$

TIME 41

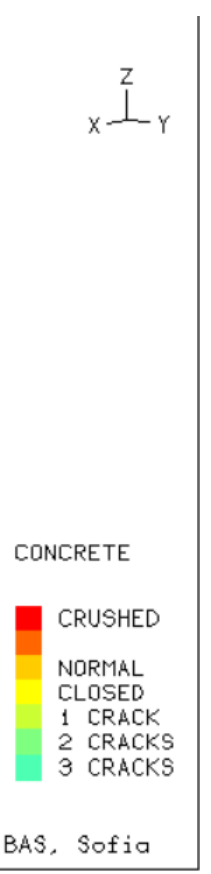

SOLVIA-POST 03

Dept. Earthquake Eng., NIGGG, BAS, Sofid

Fig. 12. Damage distribution in the bridge in longitudinal direction. Pile foundation case study.

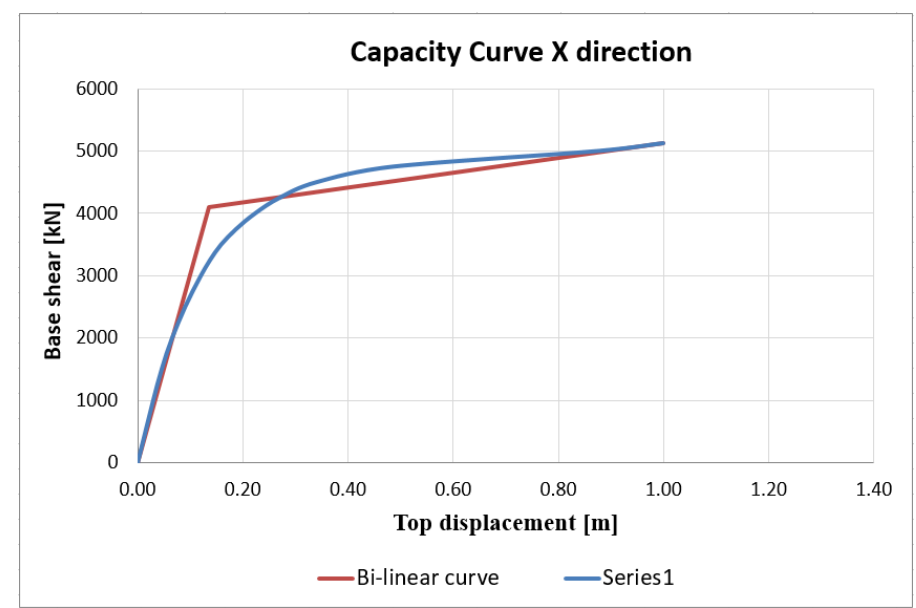

Fig. 13. Push-over (capacity) curve for the pile foundation case study

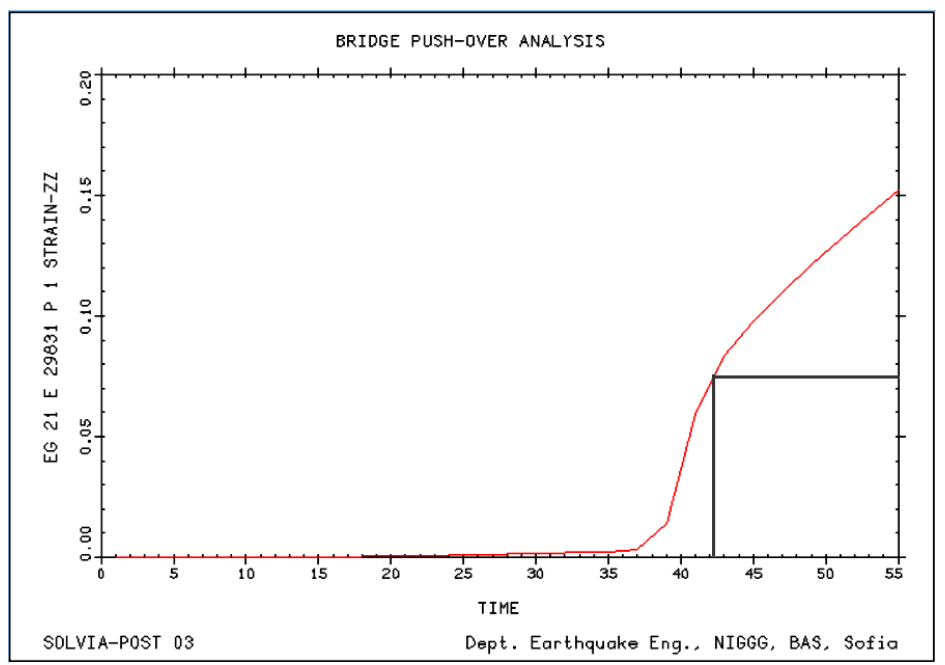

Fig. 14. Strain distribution in the tensile reinforcement at the base of the pier. Pile foundation. 


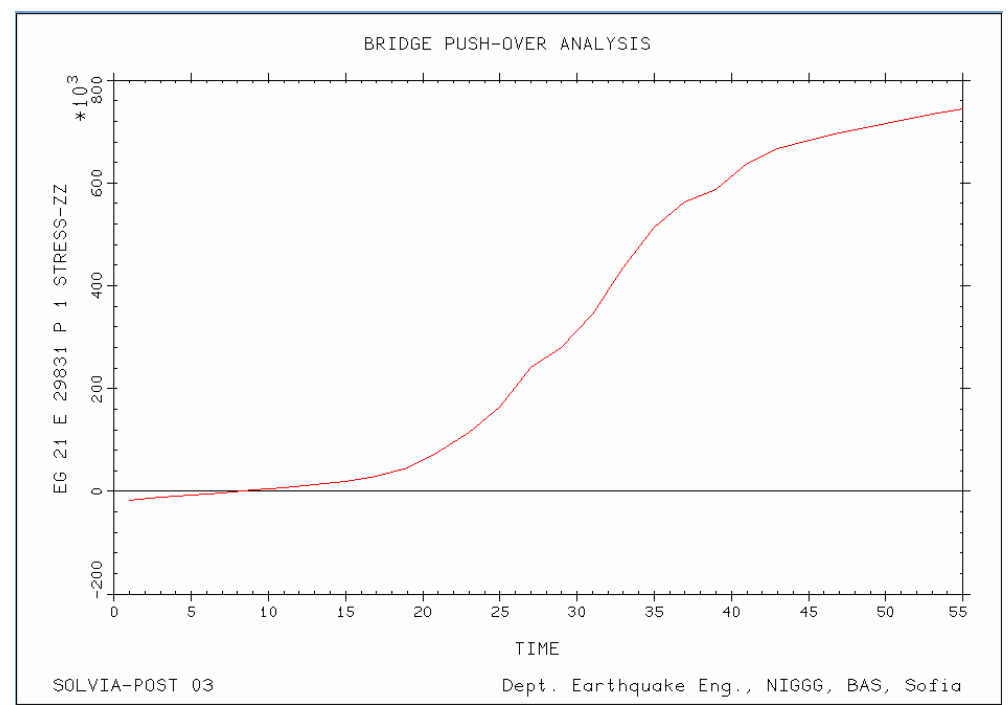

Fig. 15. Stress distribution in the tensile reinforcement at the base of the pier. Pile foundation.

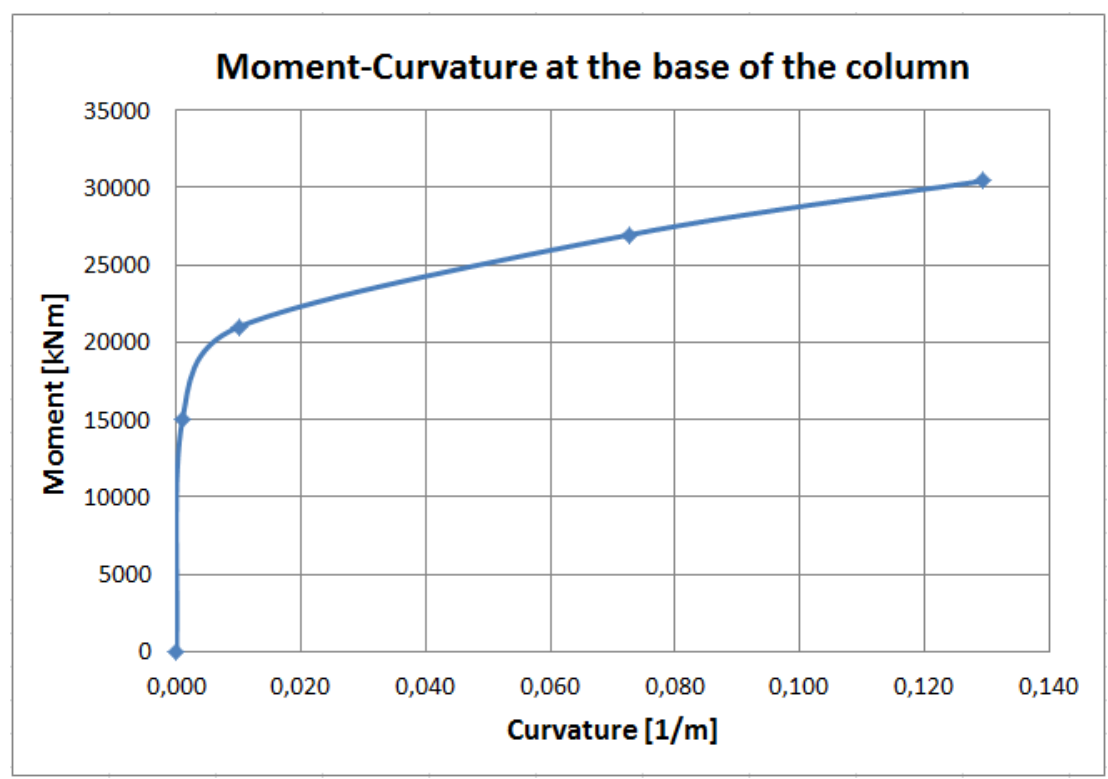

Fig. 16. Moment-curvature relationship at the base of the pier. Case study-pile foundation.

Determination of the curvature ductility factor $\mu \Phi$ in LONGITUDINAL direction in the case of FLAT foundation TAKING THE VERTICAL COMPONENT OF THE SEISMIC ACTION INTO ACCOUNT.

The analysis is performed based on the following assumptions:

- The ratio between the vertical and horizontal acceleration $\mathrm{avg} / \mathrm{ag}_{\mathrm{g}}=0.90$;

- The analysis is only for the longitudinal direction and only for the option "flat foundation";

- The design combination according to [2] is "E $E_{x}+" 0.30 E_{z} "$
The results are presented in Fig.17. The curvature ductility is:

$$
\mu_{\Phi}=\Phi_{u} / \Phi_{y}=0.025 / 0.0025=10
$$

This value is less than the determined without taking the vertical seismic action into account $-\mu \phi=14.73$.

This result shows that the vertical seismic action reduces the ductility and should not be neglected. 


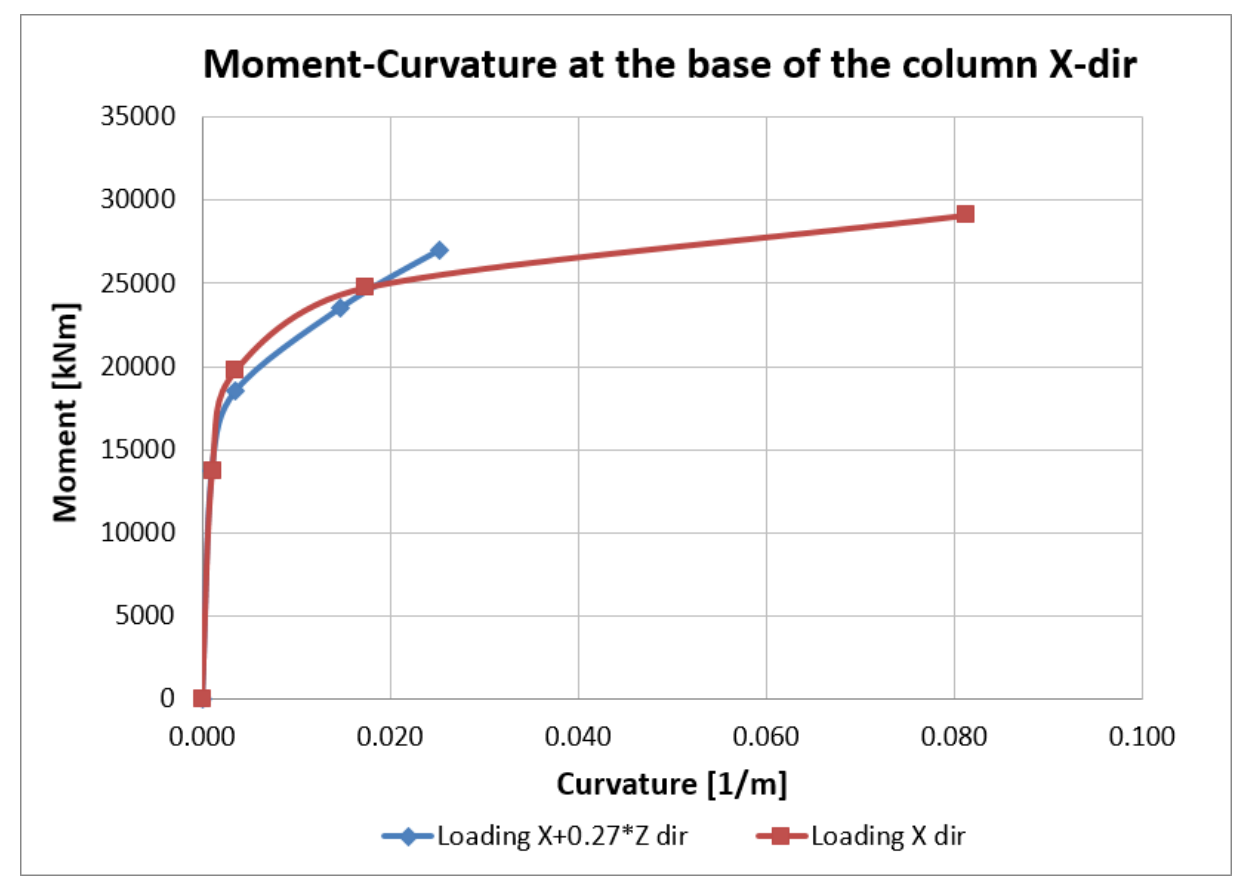

Fig. 17. Moment-curvature relationship at the base of the pier-comparison with/without VERTICAL seismic action

\section{CONCLUSIONS}

The ductility of the frame type bridges has been analyzed using nonlinear static analysis (push-over). The main results from the analysis of the presented bridge structure are:

- The ductility in the longitudinal direction in the case of flat foundation is higher than one in the transversal direction. The calculated displacement ductility factor $\mu_{d}=4.29$ in TRANSVERSAL direction is still higher than the value of the behaviour coefficient from EN 1998-2 [1] $-q=3.5$.

- The calculated displacement ductility factor $\mu_{d}$ for the case "flat foundation" is higher than one for the case "pile foundation" - see Fig.18.

- The vertical seismic component should be always taken into account due to the reduced bridge member ductility
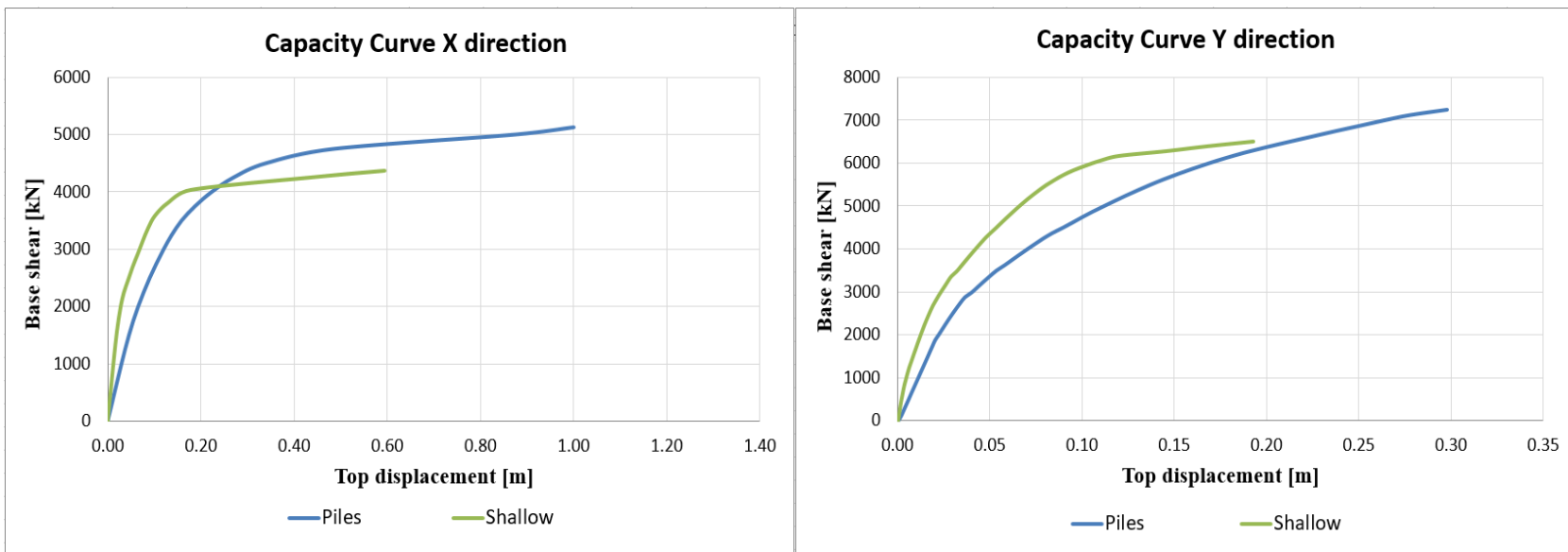

Fig. 18. Push-over (capacity) curve comparison 


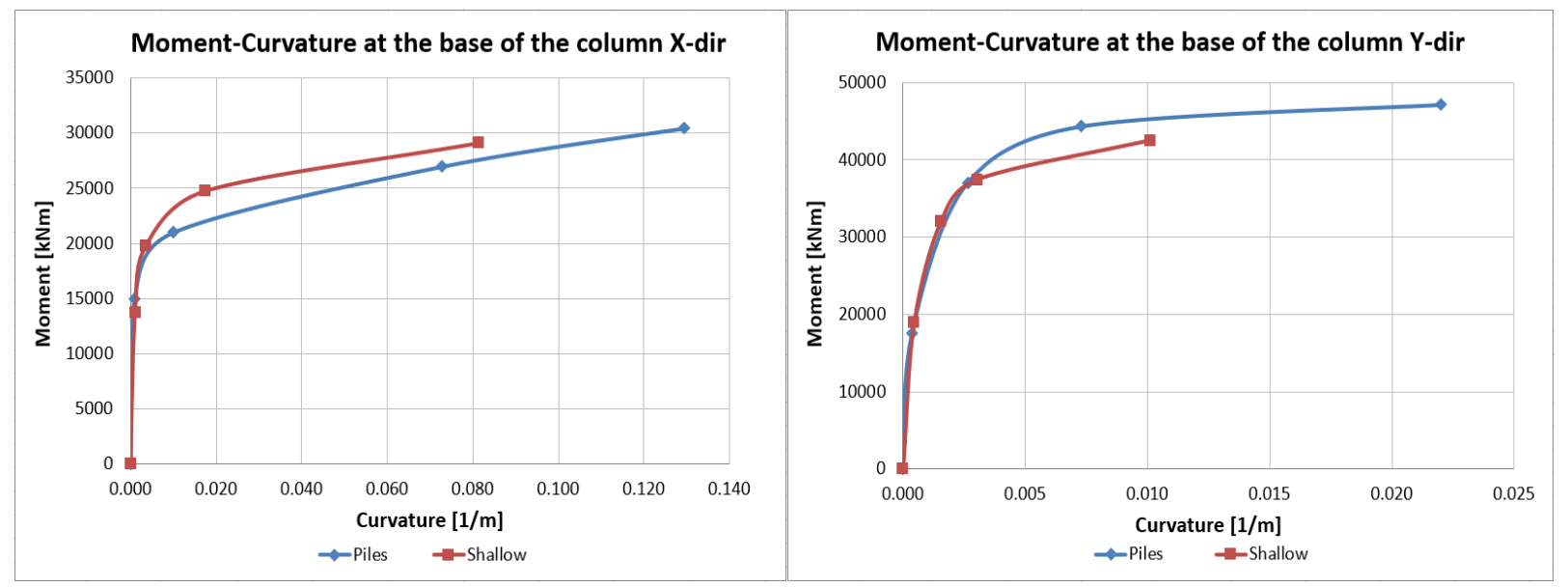

Fig. 19. Moment-curvature relationship at the base of the pier-comparison

\section{ACKNOWLEDGEMENTS}

This study is financially supported by „Program for the promotion of research in the field of environmental protection and reduction of the risk of adverse events and natural disasters“, WP.I.10. „Assessing the dangers of catastrophic earthquakes and their consequences".

\section{ABSTRACT}

\section{NON-LINEAR ANALYSIS OF FRAME REINFORCED CONCRETE BRIDGE- SHALLOW VS. PILE FOUNDATION}

\section{Alexander ILIEV \\ Dimitar DIMITROV \\ Dimitar STEFANOV}

The paper presents the application of the non-linear (push-over) analysis for a selected frame reinforced concrete bridge which meets the requirements of [1] Two options for the foundations are considered - flat and pile ones. Comparison between the structural ductility in longitudinal and transversal direction is made. The vertical component of the earthquake action is taken into account and the influence to the ductility is analyzed.

Key words: Bridges, Non-Linear Analysis, Eurocode, Ductility

\section{REFERENCES}

[1] Eurocode 8 - Design of structures for earthquake resistance. Part 2: Bridges.

[2] Eurocode 8 - Design of structures for earthquake resistance. Part 1: General rules, seismic actions and rules for buildings.

[3] SOLVIA Finite Element System. User manual. SOLVIA Engineering AB, Vasteras, Sweden, 2003.

[4] Sheikh, S.A., Uzimeri, M. Strength and Ductility of Tied Concrete C, Journal of the Structural Division, Vol.108, ST12, 1982.

[5] Priestley, M.J.N, Seible, F., Calvi, G.M. Seismic Design and Retrofit of Bridges, JOHN WILEY \&SONS, INC.,New York, 1996.

[6] Fletcher, Roger. Practical methods of optimization (2nd ed.), New York: John Wiley \& Sons, 1987.

[7] Len Schwer. The Winfrith Concrete Model: Beauty or Beast? Insights into the Winfrith Concrete Model, 8th European LS-DYNA Users Conference, Strasbourg, 2011.

\section{REZIME}

\section{NELINEARNA ANALIZA OKVIRNOG AB MOSTA FUNDIRANOG NA PLITKIM TEMELJIMA I NA ŠIPOVIMA}

\section{Alexander ILIEV \\ Dimitar DIMITROV \\ Dimitar STEFANOV}

$\mathrm{U}$ radu je prikazana primena nelinearne (push-over) analize za okvirni armirano-betonski most prema zahtevima izloženim u [1]. Razmatrane su dve opcije fundiranja - plitko fundiranje i fundiranje na šipovima. Upoređena je duktilnost konstrukcije u podužnom i poprečnom pravcu. Uzeta je u obzir i vertikalna komponenta zemljotresnog dejstva i analiziran je njen uticaj na duktilnost konstruktivnog sistema.

Ključne reči: Mostovi, Nelinearna analiza, Evrokod, Duktilnost 